\title{
Nasjonal helse-
}

og sykehusplan

- i korte trekk
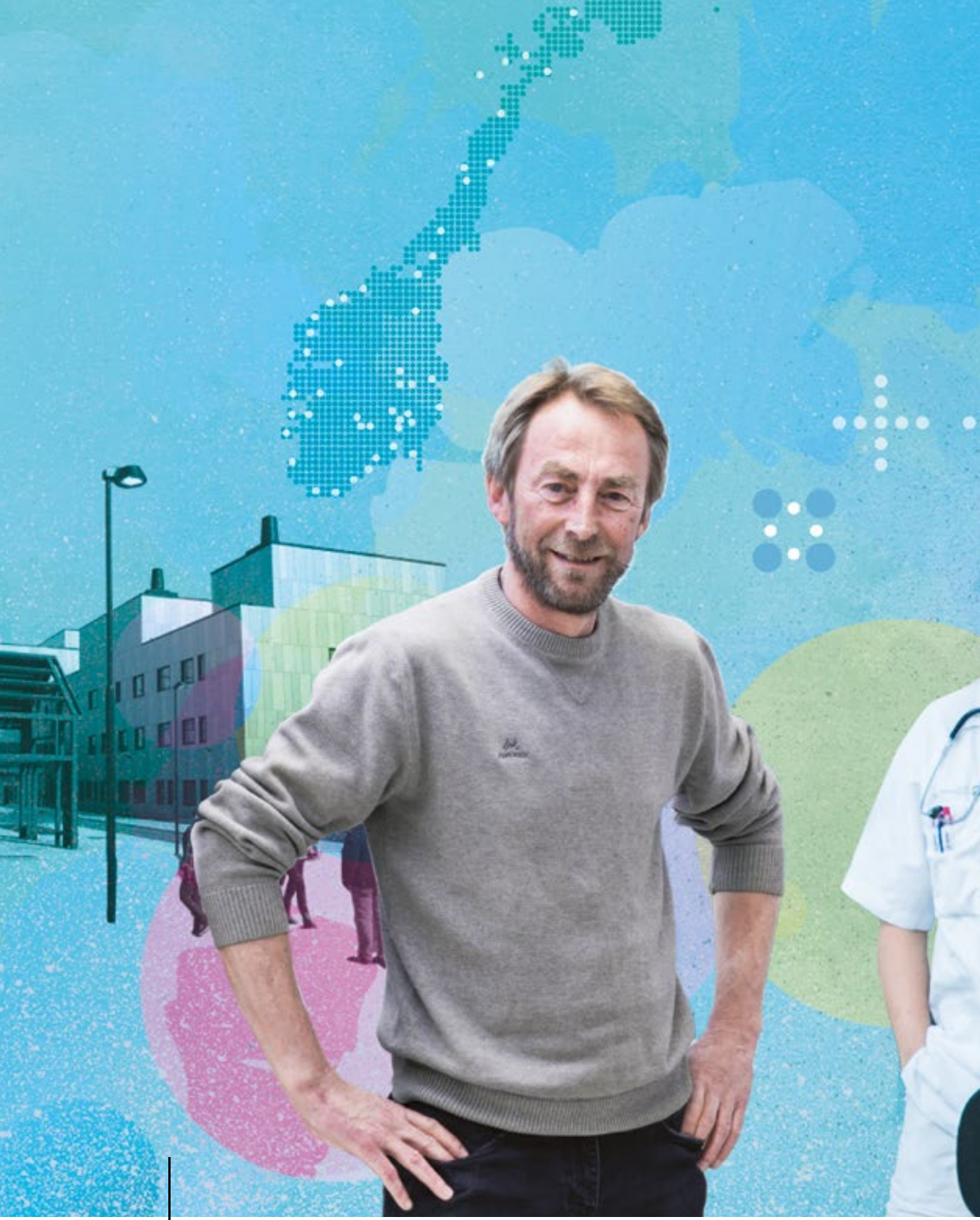
Vi blir flere, vi blir eldre og vi bosetter oss mer i byer og tettsteder. Noen sykdommer blir mindre truende, andre vokser i omfang. Vi kan behandle mer og flere.

Utfordringen som dette gir for helsetjenesten, er svært omfattende. Det å bare fortsette som nå er ikke et bærekraftig alternativ. Vi må ha en konkret plan for å ruste helsetjenesten for framtiden.

Vi trenger både det store og det lille sykehuset i morgendagens helsetjeneste. Men vi må bruke dem på en klokere måte. Derfor skal ulike sykehus i framtiden jobbe sammen som team. Da vil pasientene få et mer samlet tilbud nær der de bor.

Skal framtidens pasienter få framtidens behandling, må vi sikre at vi har den rette kompetansen i helsetjenesten. Da må vi planlegge bedre. De som skal arbeide i sykehusene i framtiden, starter på sin utdanning i dag.

Sykehusene skal ha ulike roller og oppgaver, men kravet til kvalitet skal være det samme. Vi vil at sykehusene våre skal være best. Men vi vil at de skal være best på hver sine områder. Store sykehus har tatt på seg oppgaver som små sykehus i pasientens nærmiljø klarer best.

Fornye, forenkle og forbedre helsetjenesten betyr å styre mer etter kvalitet. Målet vårt er først og fremst gode helsetjenester for pasientene. Vårt prosjekt er å skape pasientens helsetjeneste. Det betyr trygge sykehus og bedre helsetjenester - uansett hvor du bor.

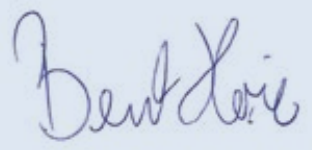

\section{Bent Høie}

Helse- og omsorgsminister 


\section{Trygge sykehus og bedre helse- tjenester - uansett hvor du bor}

\section{Nasjonal helse- og sykehusplan handler om}

- pasienter som deltar aktivt i beslutninger om egen behandling og utvikling av helsetjenesten

- ansatte i riktig antall og med riktig kompetanse som får brukt tiden sin riktig

- sykehus som har klar oppgavedeling og som arbeider sammen i team

- kvalitet utvikler helsetjenesten. Vi styrer etter kvalitet 


\section{Hvorfor trenger vi Nasjonal helse- og sykehusplan}

\section{Vi blir 1 million flere i 2030}

- $50 \%$ flere over 70 år i 2030

- Vi fortsetter å flytte til byene

- Andel eldre øker i spredtbygde strøk

\section{Uten endring trenger vi}

- 30000 nye helsearbeidere i 2030

- 40000 nye helsearbeidere i 2040

\section{Andel av befolkningen 67 år og} eldre. 2015
Andel av befolkningen 67 år og

eldre. 2030
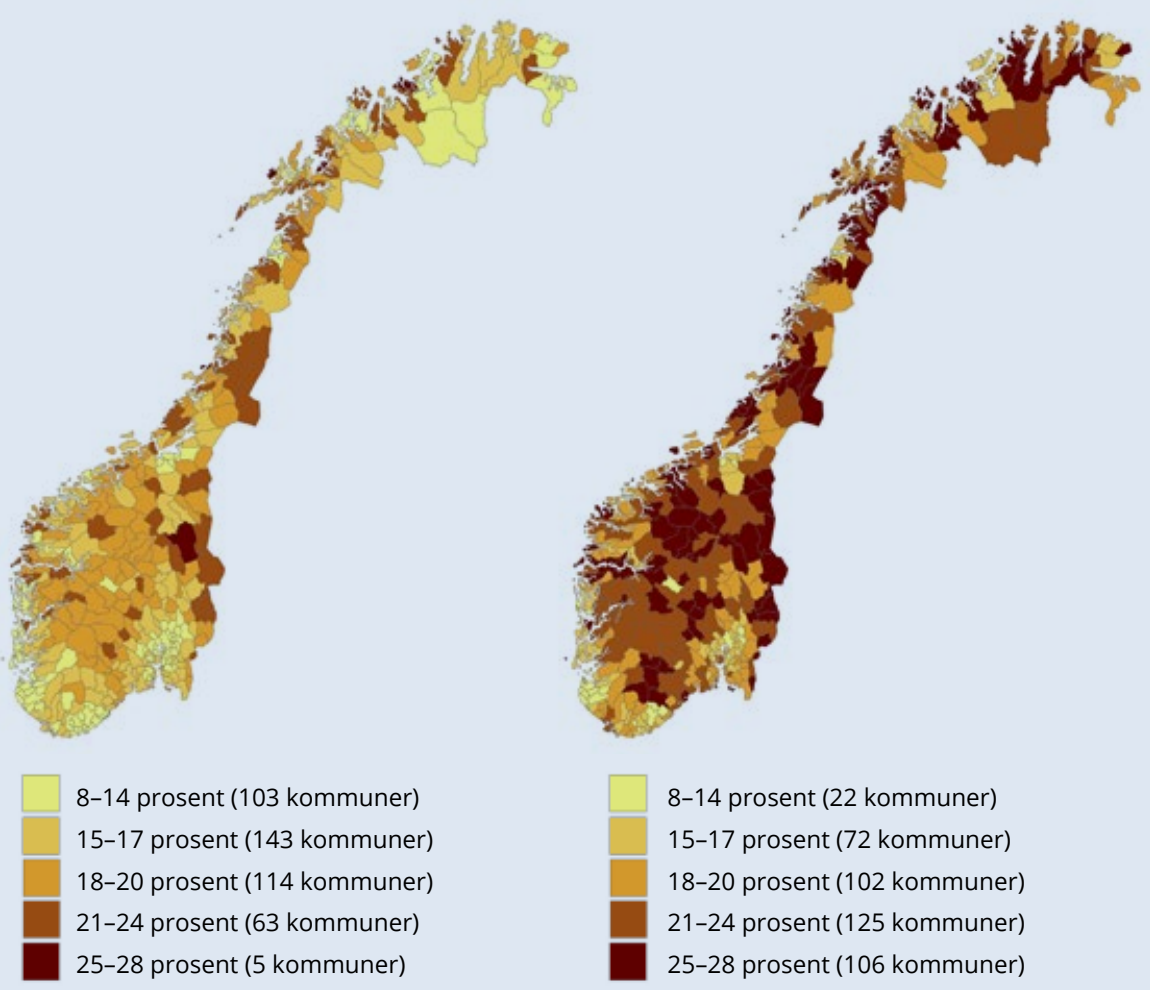

8-14 prosent (22 kommuner)

15-17 prosent (72 kommuner)

18-20 prosent (102 kommuner)

21-24 prosent (125 kommuner)

25-28 prosent (106 kommuner) 


\section{Pasientens helsetjeneste}

\section{Råd fra pasientene}

- Helsetjenesten er til for pasientene. Det skal være pasientenes helsetjeneste og ikke helsetjenestens pasienter

- I pasientens helsetjeneste er det EN helsetjeneste. Pasienten merker ikke hvem som eier, drifter og betaler - det tar systemet seg av

- For pasientene henger kropp og sinn sammen. Det må også helsetilbudet gjøre

- $\AA$ bruke pasientens evne til å mestre egen sykdom, er en medisin som brukes for lite

- Alle dagens sykehus bør beholdes, men mange bør endres og utvikles. Små sykehus kan bli helsesentre, der kommunenes helse- og omsorgstjeneste og spesialisthelsetjenesten samhandler om de helsetjenestene folk trenger der de bor

- Både kvalitet og nærhet er viktig. Kvaliteten på behandlingen skal ikke være avhengig av hvem du er og hvor du bor. Vi trenger nasjonale kvalitetskrav

- Pasienter med langvarige sykdommer trenger fast lege og kontaktsykepleier i spesialisthelsetjenesten. De skal også få tilbud om å møte en likeperson

- Helsetjenesten må ha åpningstider som passer med folks hverdag og arbeidsliv

- Helsepersonell må få bruke tiden sin på pasientene og ikke på byråkrati

- Brukermedvirkning er avgjørende for å skape pasientens helsetjeneste. Vi vil ha BRUKER MED VIRKNING OVERALT! 


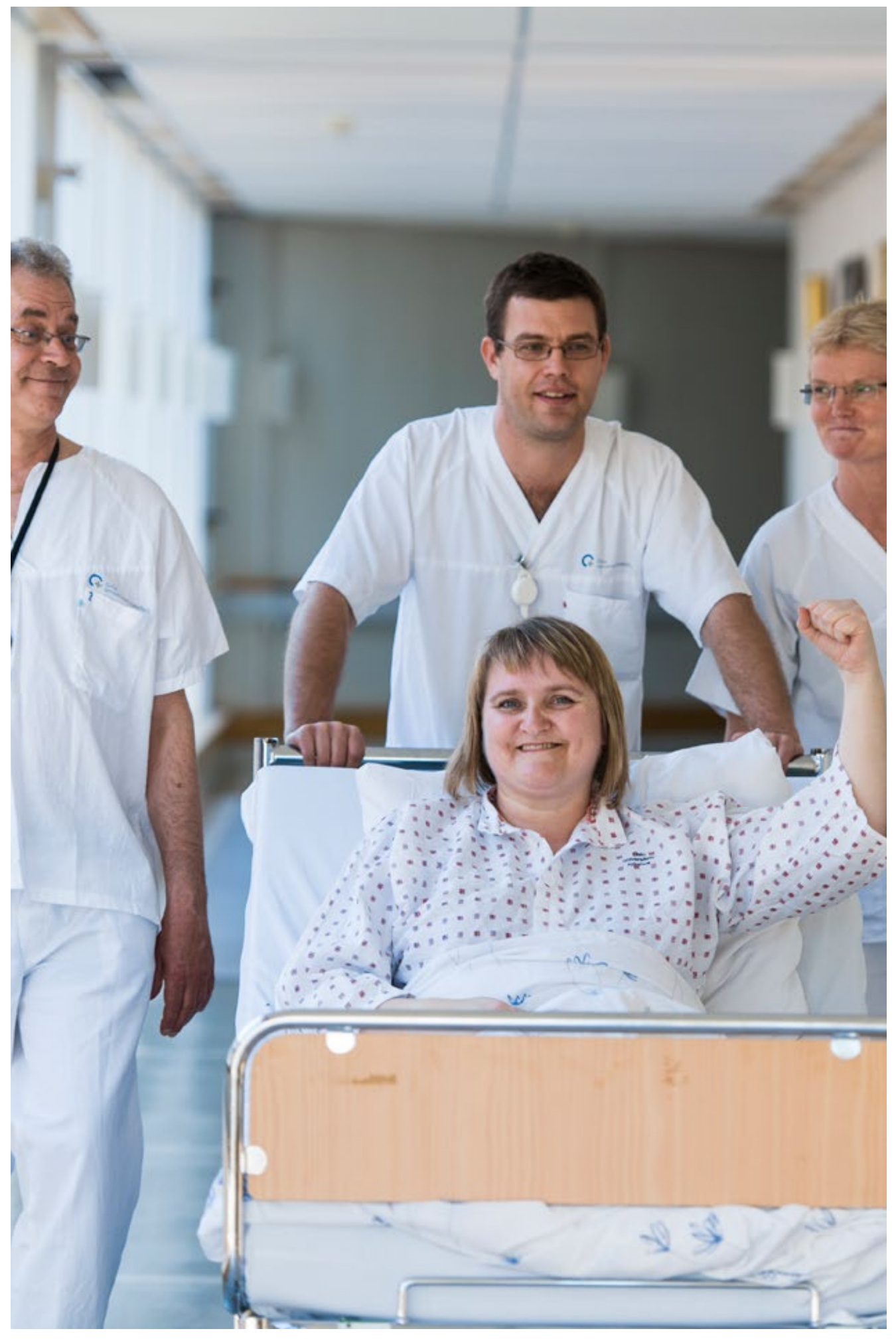




\section{De viktigste målene \\ i Nasjonal helse- og sykehusplan}

Styrke pasienten

Prioritere tilbudet innen psykisk helse og rusbehandling

Fornye, forenkle og forbedre helsetjenesten

Nok helsepersonell med riktig kompetanse

Bedre kvalitet og pasientsikkerhet

Bedre oppgavedeling og samarbeid mellom sykehus

Styrke akuttmedisinske tjenester utenfor sykehus 


\section{Styrke pasienten}

\section{Regjeringen vil}

- gjennomføre fritt behandlingsvalg

- lage pakkeforløp for flere grupper i tillegg til kreftpasienter. Pasienter med hjerneslag, psykiske helseutfordringer og rusavhengighet skal også få pakkeforløp

- gjennomføre ordningen med kontaktlege til alvorlig syke pasienter

- la pasientene delta aktivt i beslutninger om egen behandling og utvikling av helsetjenesten

- lage ungdomsråd ved alle sykehus

- bruke erfaringskonsulenter mer i helsetjenesten

- lage en opptrappingsplan for habilitering og rehabilitering

- utvikle helsenorge.no med mer informasjon og bedre digitale kommunikasjonsløsninger for pasientene

- utvikle flere gode verktøy for samvalg mellom pasienter og helsepersonell

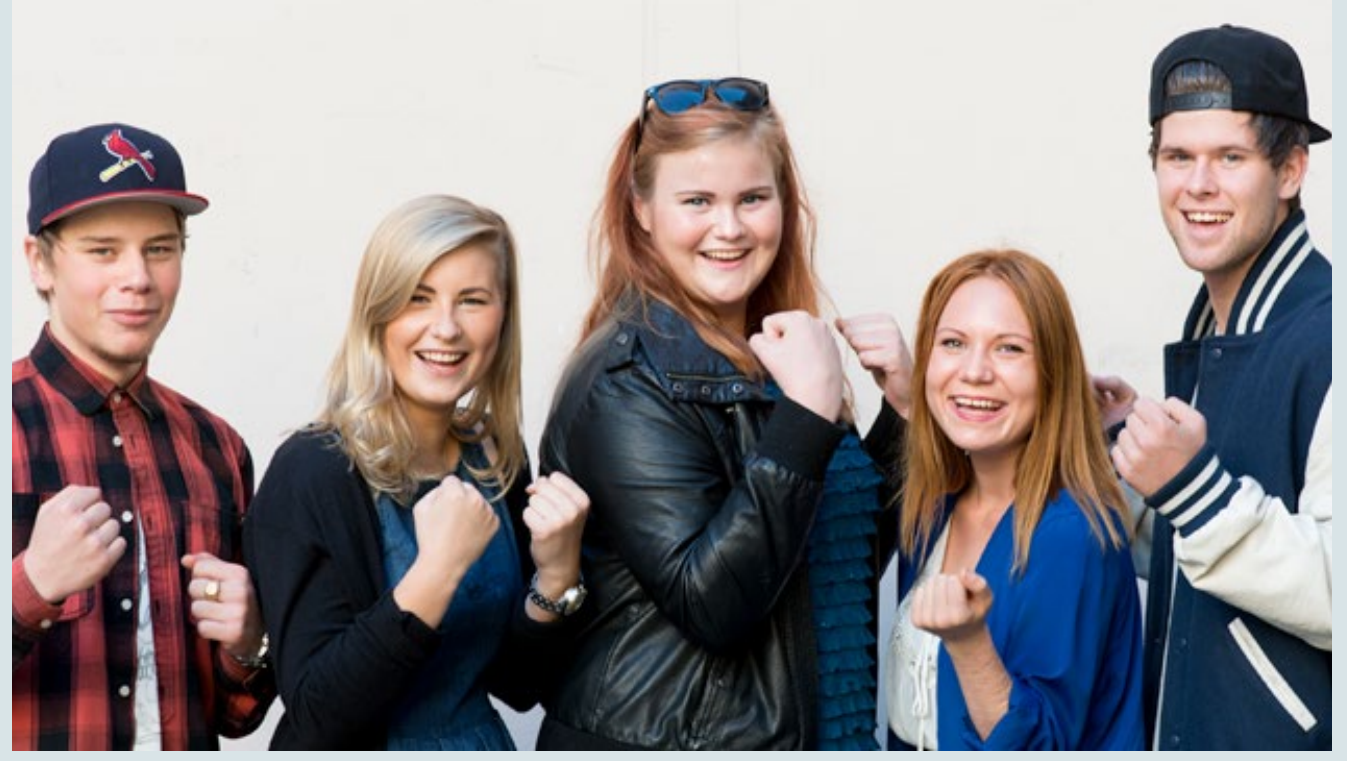




\section{En aktiv pasient}

- har lett tilgang til, forstår og bruker informasjon om helse og sykdom

- har innsyn i egen journal

- opplever likeverdighet i møte med helsepersonell

- er med å ta beslutninger om egen helse

- er med å utvikle helsetjenesten

Møtet mellom pasient og behandler blir bedre når pasienten er forberedt, enn når all informasjon kommer over bordet.

\section{Se hvordan de gjør det ved Universitetssykehuset $i$ Nord-Norge}

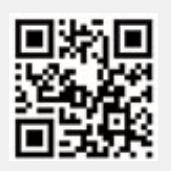

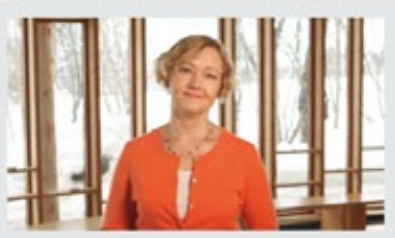

Tryex pa knappen med an daynose for i stante

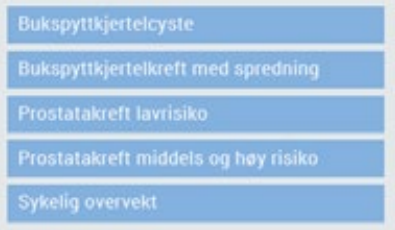

Hvis pasienten fikk bestemme

Se hvordan resultatet ble da brukernes erfaringer ga form til nytt Brystdiagnostisk senter ved Oslo universitetssykehus.

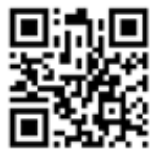

\section{Pasienten kan kommunisere med sykehuset}

Pasientene i Helse Vest kan kommunisere med sykehuset via Vestlandspasienten.no. De kan endre time, se hvor henvisningen befinner seg og sende meldinger til avdelingene. Les mer
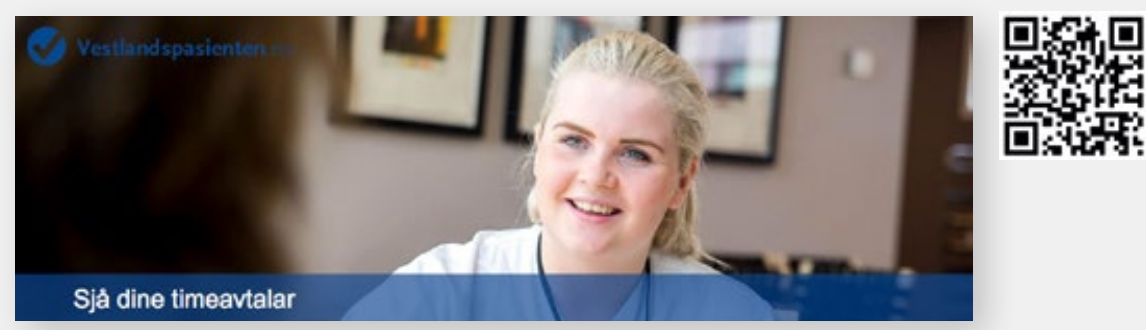


\section{Prioritere tilbudet i psykisk helse og rusbehandling}

\section{Regjeringen vil}

- prioritere tilbudet i psykisk helsevern og tverrfaglig spesialisert rusbehandling

- myke opp skillet mellom psykiske og somatiske helsetjenester, så pasienter som trenger behandling for både kropp og sinn, får det - samtidig

- innføre pakkeforløp for psykisk helse

- innføre pakkeforløp for rusavhengige

- videreføre utviklingen av døgnberedskap og ambulante akuttjenester ved de distriktspsykiatriske sentrene

- vurdere bedre oppgavedeling mellom små og store distriktspsykiatriske sentre og barne- og ungdomspsykiatriske sentre

- følge opptrappingsplanen for rusfeltet

- lage et nasjonalt kvalitetsregister for rusbehandling

Sosial angst, depresjon og panikklidelse behandles via nettet i Helse Vest. Se hvordan
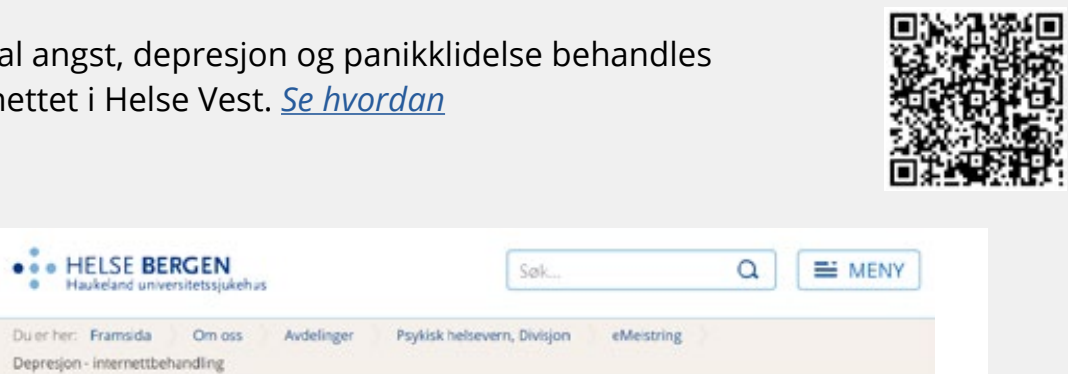

Depresjon - internettbehandling

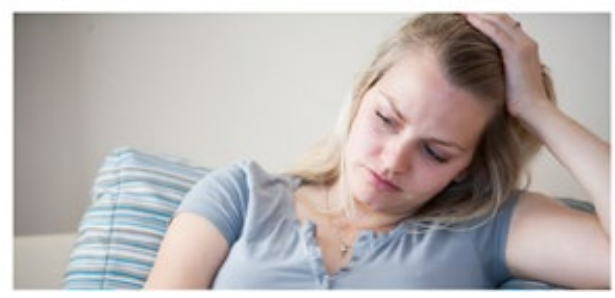

elveistring

eMeistring - forsida ,

Sosial angst >

Panikkliding > 


\section{Hjelp der du bor}

\section{Akutt hjemmebehandlingsteam i Ålesund}

Pasienter som har akutt behov for psykiatrisk hjelp, vurderes innen fire timer. Omtrent halvparten av akuttinnleggelsene unngås.

\section{"Gevinsten ved å behandle pasienten hjemme er ikke at vi gjor det samme ute, men at vi forstår noe annet, og kan bruke andre verktøy» \\ Les mer}

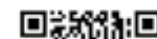
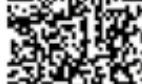

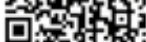

Videokonferanse

Helse Nord - flytter

spesialisten til pasienten

Les mer
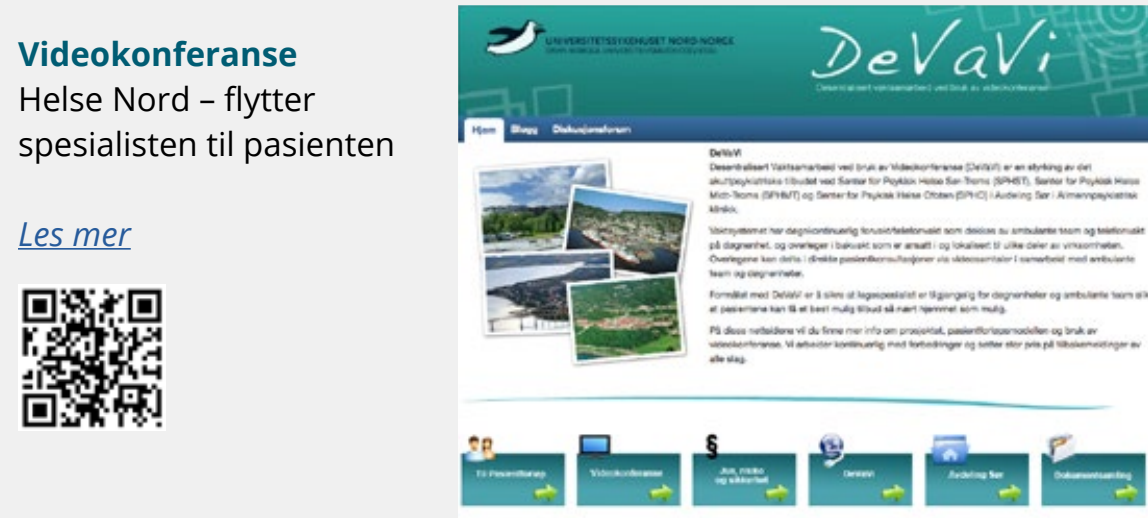

Brukerstyrte plasser der pasienten kan legge seg inn selv på distriktspsykiatrisk senter uten å gå om fastlegen, har ført til færre sengedøgn. 


\section{Fornye, forenkle og forbedre helsetjenesten}

\section{Regjeringen vil}

- få sykehusene til å utnytte ledig kapasitet enda bedre

- styrke samarbeidet med private helsetjenester

- oppmuntre til å endre oppgavedelingen mellom helsepersonell der det kan fjerne flaskehalser og skape bedre kvalitet i pasientbehandlingen

- bruke moderne IKT-løsninger mer i alle deler av helsetjenesten

- lage et nasjonalt program for behandlingsforskning så flere pasienter kan få tilgang til ny, utprøvende behandling

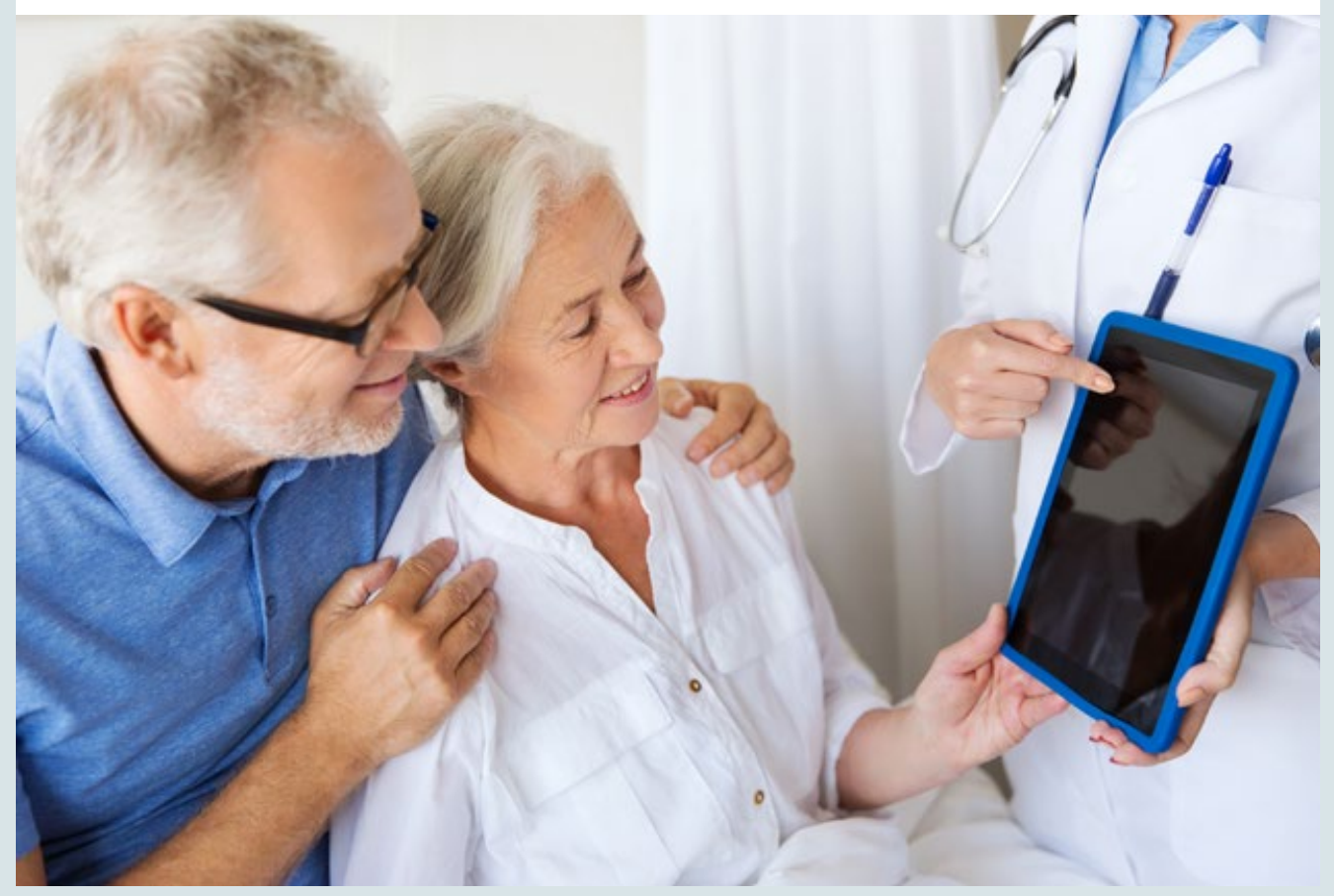




\section{Dette skjer nå}

Telemedisin flytter kompetanse

Store sykehus deler spesialistkompetanse med mindre sykehus og distriktmedisinske sentre. Les mer
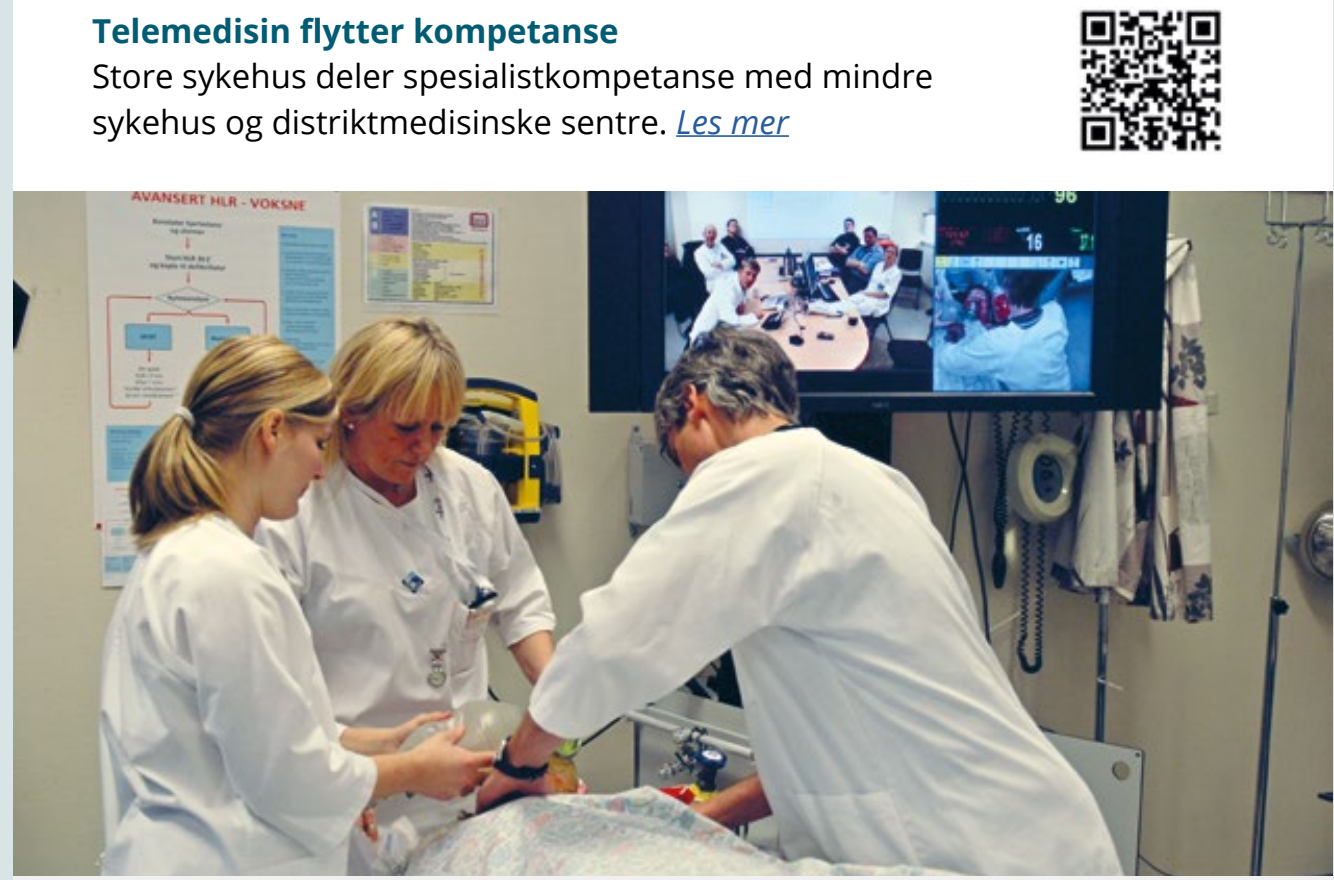

Pasienten kan lese journalen sin på nettet

Alle pasienter i Helse Nord får elektronisk tilgang til sin journal i løpet av 2015. Pasientene forstår innholdet og vil fortsette å bruke løsningen. Les mer

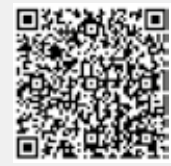

Sykehuset Østfold forbedrer pasientflyten med IKT

Nytt sykehus bruker nye løsninger

Se hvordan
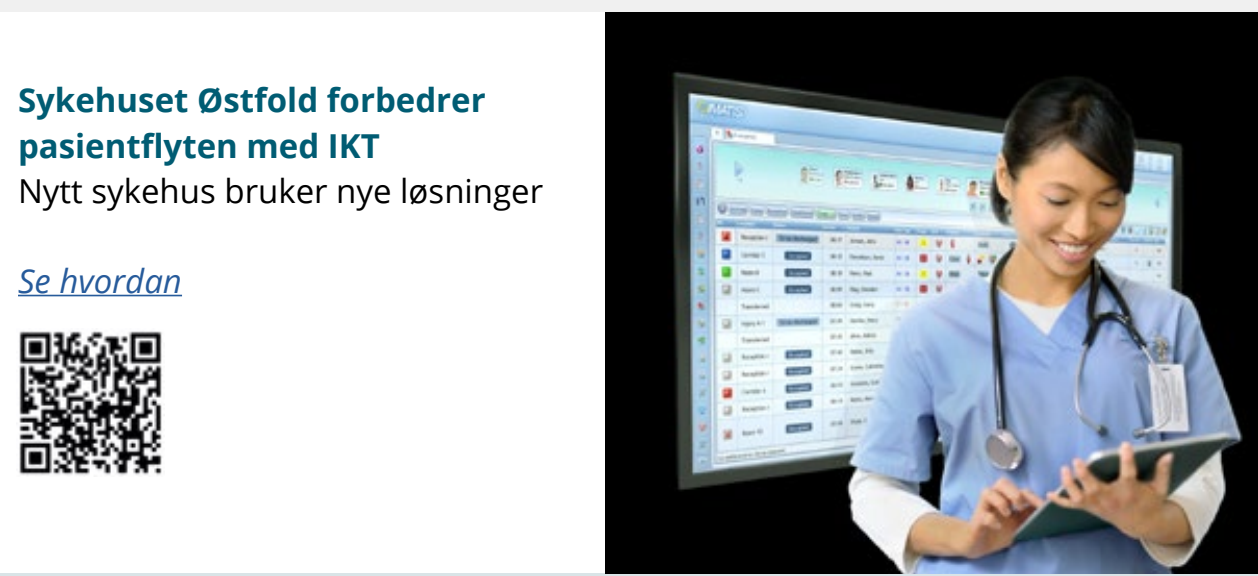


\section{Nok helsepersonell med riktig kompetanse}

\section{Regjeringen vil}

- gjennomføre ny modell for utdanning av legespesialister

- lage en ny legespesialitet innrettet mot akuttmottakene i sykehus

- vurdere nytt videreutdanningstilbud i avansert klinisk sykepleie i sykehus

- sikre bedre samsvar mellom utdanningenes innhold, studentenes sluttkompetanse og helsetjenestens behov

- forbedre kunnskapen om personell- og kompetansebehov i framtidens spesialisthelsetjeneste som grunnlag for å møte behovene for helsepersonell og utvikle utdanningene

- bruke den nye, nasjonale bemanningsmodellen for å planlegge behovet for helsepersonell regionalt og lokalt

- at e-læring og simulatortrening brukes mer for å styrke kompetanse og ferdigheter

\section{Behov for helsearbeidere $\mathbf{2 0 3 0 - 4 0}$}

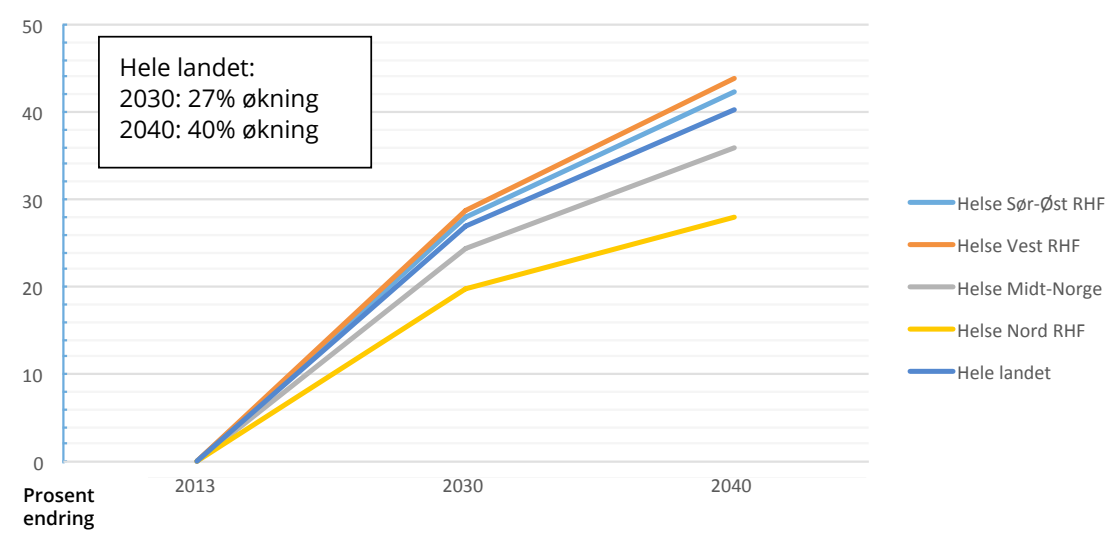




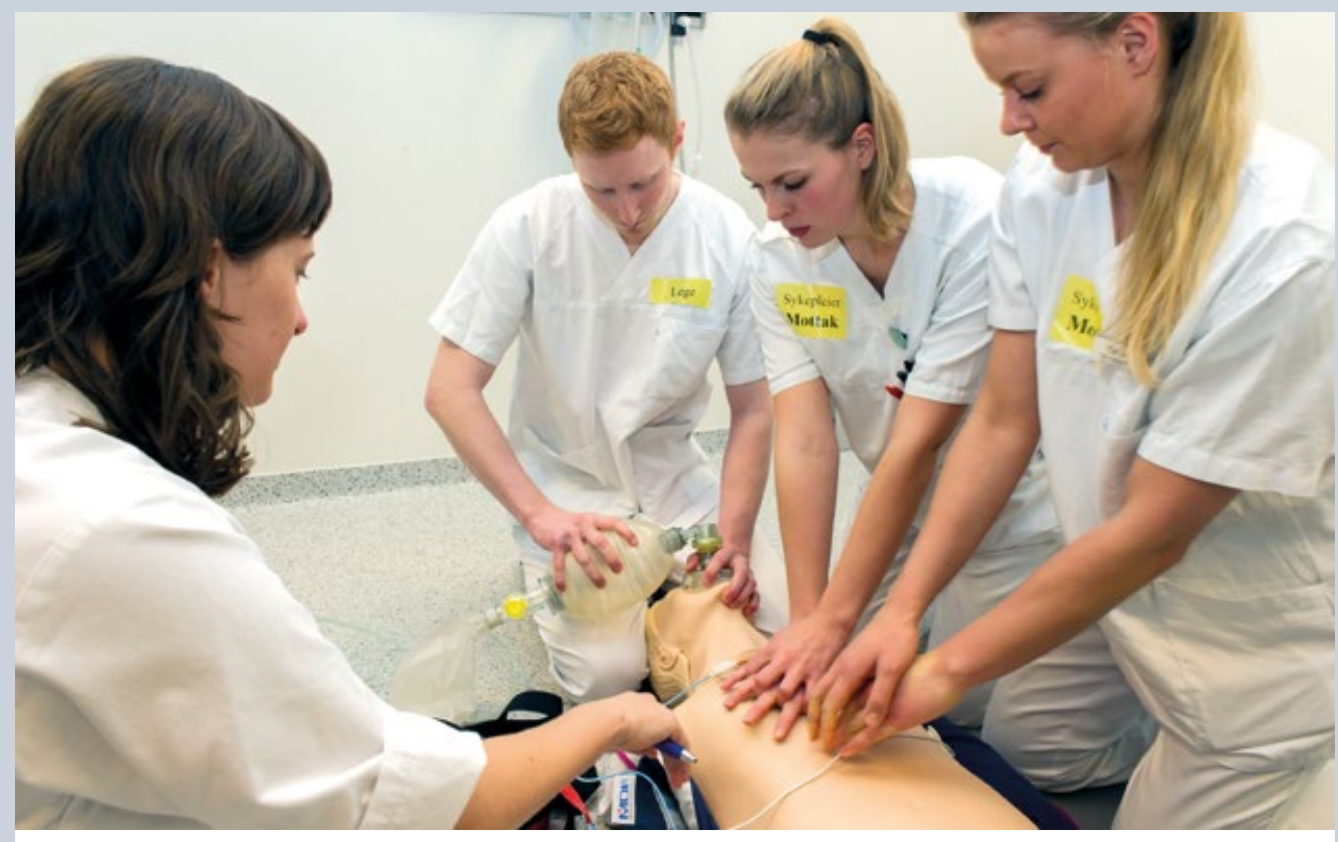

For å jobbe i team, må vi lære i team

Universitetet $i$ Troms $\varnothing$ har samlet alle helsefaglige utdanninger. Studenter får opplæring i tverrfaglig samarbeid, og følger en fagperson fra en annen profesjon på jobb. Se hvordan
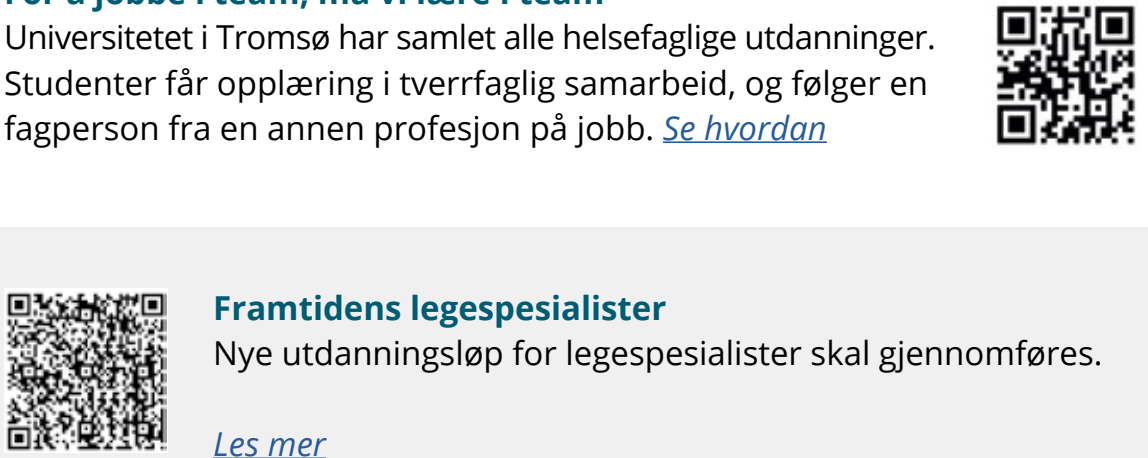

Framtidens legespesialister

Nye utdanningsløp for legespesialister skal gjennomføres.

Les mer

Hvor mange av hver?

Nasjonal bemanningsmodell

Ny modell viser samlet behov for alle typer personell.

Les mer
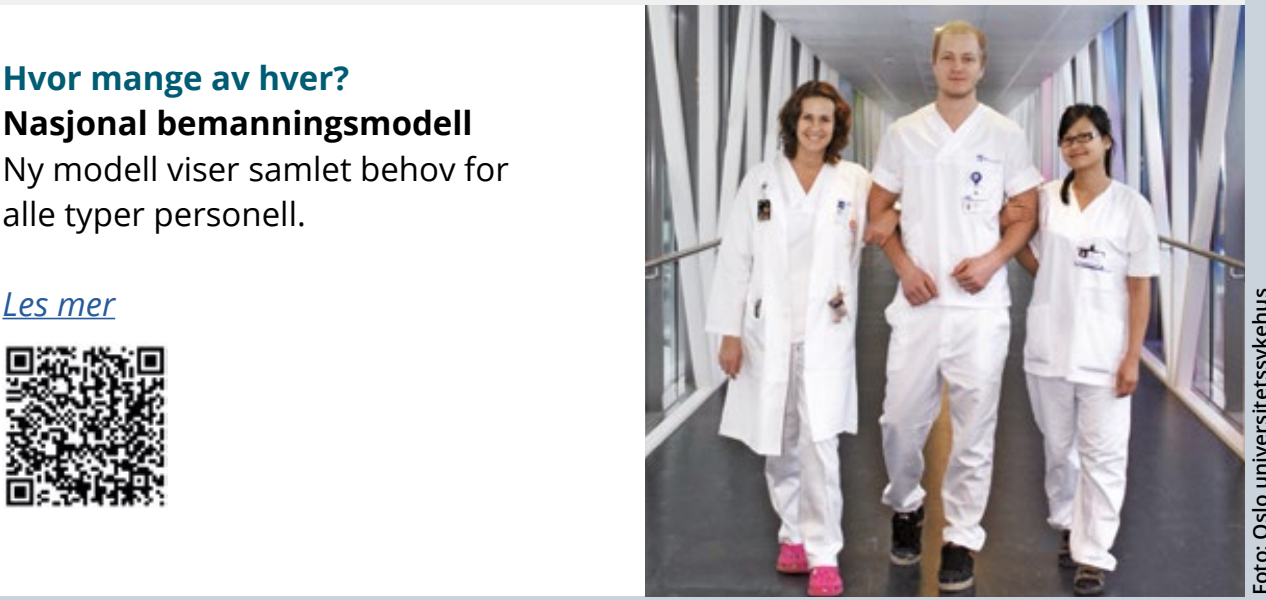


\section{Bedre kvalitet og pasientsikkerhet}

\section{Regjeringen vil}

- videreutvikle gode mål for kvalitet og pasientsikkerhet som kan brukes i kvalitetsarbeid på alle nivåer

- lage nasjonale kvalitetskrav til behandlingstilbud der det er nødvendig for å sikre likeverdig kvalitet

- innføre nasjonal godkjenning av behandlingstilbud som skal samles på få steder i helseregionene, og gi Helsedirektoratet myndighet til å godkjenne slike regionale behandlingstjenester

- skape bedre kvalitet og tryggere tjenester ved sertifisering av sykehusene

- lage et nasjonalt nettverk for fagrevisjoner i sykehus så fagfolk kan studere og lære av hverandre

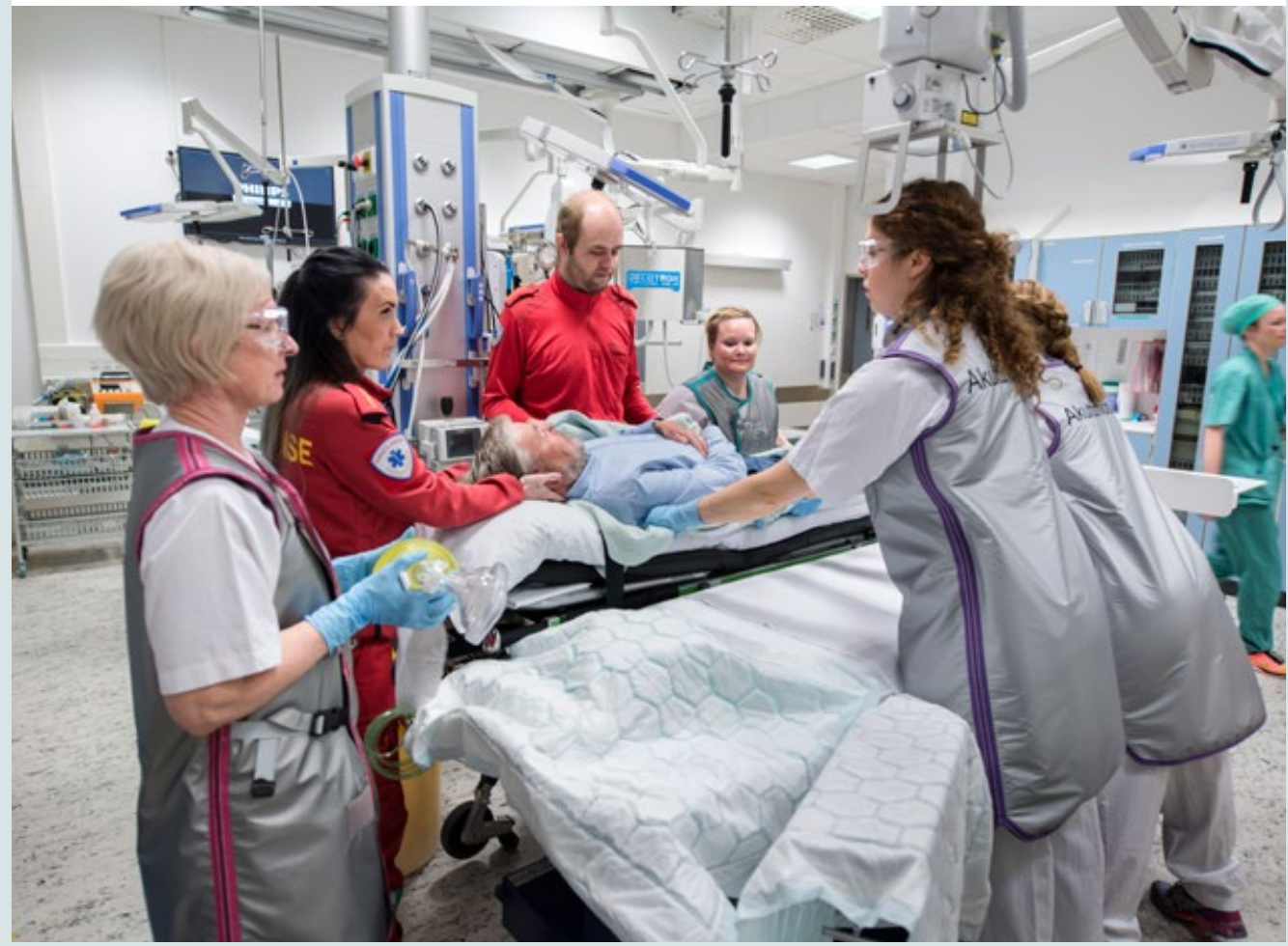




\title{
Bedre kvalitet og pasientsikkerhet
}

\author{
«Det må vaere full åpenhet om kvalitet, \\ og pasientopplevd kvalitet må veie tyngre \\ - likeverdig med medisinsk kvalitet»
}

Ekspertgruppen av pasienter og pårørende til Nasjonal helse- og sykehusplan

helsenorge $\cdot$ no

Oversikt over kvalitetsindikatorer

exinu

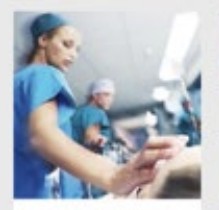

Behandling av sykdom og overlevelse

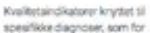

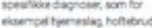

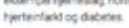

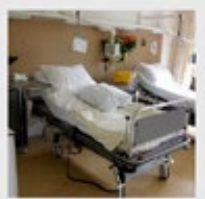

Sykehusopphold knaltecundiutore los birt emeropiestersinge os
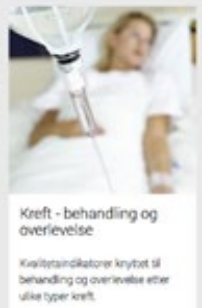

På www.helsenorge.no er det nå 83 nasjonale kvalitetsindikatorer for helsetjenesten.

\section{Les mer}

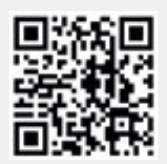

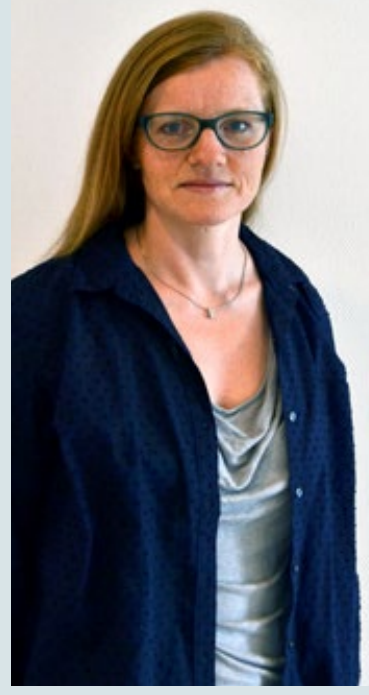

Helse Nord-Trøndelag sertifiserte psykiatrien i 2005. Nå sertifieres hele helseforetaket

"Gi oss klare kvalitetskrav som gjelder for alle. Det skal ikke vaere mindre krav til små sykehus, vi skal vaere like gode på det vi gjør som universitetssykehusene er på det de gjør. Still kvalitetskrav, men gi oss frihet til å finne losningene lokalt»

Kathinka Meirik, Klinikkleder Psykiatri, Helse Nord-Trøndelag 


\section{Bedre oppgavedeling og samarbeid mellom sykehusene}

\section{Skal bygge på disse prinsippene:}

- Det skal fortsatt være en desentralisert og differensiert sykehusstruktur i Norge. En ryggrad av akuttsykehus er nødvendig for å sikre beredskap og øyeblikkelig hjelp.

- Funksjoner skal samles når det er nødvendig av hensyn til kvalitet, men samtidig desentraliseres når det er mulig - for å gi et bredest mulig tilbud med god kvalitet $\mathrm{i}$ nærmiljøet.

- For pasienter med behov for mer spesialiserte akutte tjenester, vil behandlingstilbudet som hovedregel være ved store akuttsykehus. Dette betyr at over tid vil færre sykehus enn i dag ha akutt kirurgi. Anbefalt nedre grense for opptaksområdet for akutt kirurgi på 60-80 000 innbyggere tas inn som en av flere føringer i denne vurderingen. Faktorer som geografi og bosettingsmønster, avstand mellom sykehus, tilgjengelighet til bil-, båtog luftambulansetjenester og værforhold skal også tillegges stor vekt.

- Andre akuttsykehus skal behandle pasienter med vanlige tilstander som har behov for øyeblikkelig hjelp i sykehus.

- De nasjonale kvalitetskravene til fødetilbudet som er nedfelt i stortingsmeldingen En gledelig begivenhet (2008-2009) og i Helsedirektoratets veileder Et trygt fødetilbud fra 2011, ligger fast. Ved endringer i tjenestetilbudet må det sikres at fødeavdelingenes behov for faglige støttefunksjoner er dekket.

- Vesentlig endring i oppgavedeling mellom sykehus må avklares i lokale prosesser der kommunene også skal høres.

- Det skal utarbeides et eget kvalitetssikringssystem for helseforetakenes arbeid med utviklingsplaner, i form av en veileder, for å understøtte at endringer i virksomheten er i tråd med nasjonale føringer, og sikre at det er gjennomført gode lokale prosesser.

- Stille krav om forpliktende nettverk mellom sykehus og helseforetak i helseregionene. Nettverkene skal sikre hensiktsmessig oppgavedeling. De skal også sikre samarbeid om pasientforløp, bemanning, utdanning av helsepersonell og hospiterings- og ambuleringsordninger.

- Sykehusstruktur og ambulansetjenester må sees i sammenheng. Endret oppgavedeling må følges av nødvendig styrking av ambulansetjenesten.

- Desentraliserte spesialisthelsetjenester, gjerne samlokalisert med kommunale helse- og omsorgtjenester, skal videreutvikles for å gi gode tjenester i nærmiljøet og helhetlige pasientforløp. 


\section{Sykehus i team}

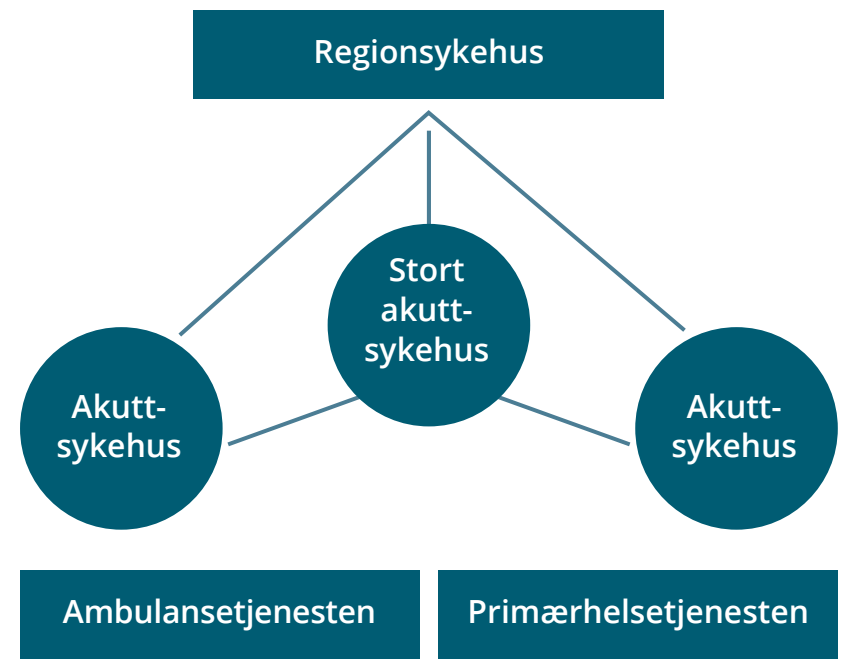

- Regionsykehuset er hovedsykehuset i helseregionen: Universitetssykehuset i Nord-Norge, St. Olavs Hospital, Haukeland universitetssjukehus og Oslo universitetssykehus

- Stort akuttsykehus har et befolkningsgrunnlag på minst 60-80 000 innbyggere og et bredt tilbud innen akuttkirurgi og andre medisinske spesialiteter

- Akuttsykehus skal minst ha akuttfunksjon i indremedisin, anestesilege i døgnvakt og planlagt kirurgi. Sykehuset kan ha akuttkirurgi hvis bosettingsmønster, avstand mellom sykehus, bil-, båt-, og luftambulansetjenester og værforhold gjør det nødvendig

- Sykehus uten akuttfunksjoner (elektive sykehus)

Sykehus i team, riktig pasient til riktig sykehus Helse Førde består av et stort akuttsykehus og to akuttsykehus. Den mest erfarne legen sørger for at riktig pasient kommer til riktig sykehus og er med på behandlingen uansett hvor pasienten Innlegges.

\section{Se hvordan}




\section{Bedre akuttmedisinsk behandling før pasienten kommer til sykehuset}

\section{Regjeringen vil}

- at utredninger av endret oppgavedeling mellom sykehus skal omfatte prehospitale tjenester, og sikre at disse har nødvendig kapasitet og kompetanse

- at kapasitet og basestruktur for luftambulansetjenesten skal gjennomgås i lys av føringene i Nasjonal helse- og sykehusplan og akuttutvalgets rapport

- at samarbeidsavtalene mellom helseforetak og kommuner skal bli felles planleggingsverktøy for akuttmedisinske tjenester

- styrke forskning og utviklingsarbeid i akuttmedisin ved å etablere fagnettverk basert på dagens kompetansemiljøer

- lage flere nasjonale retningslinjer, veiledere og standarder i akuttmedisin

- igangsette nasjonale pilotprosjekter for utdanning i ambulansefag på bachelornivå

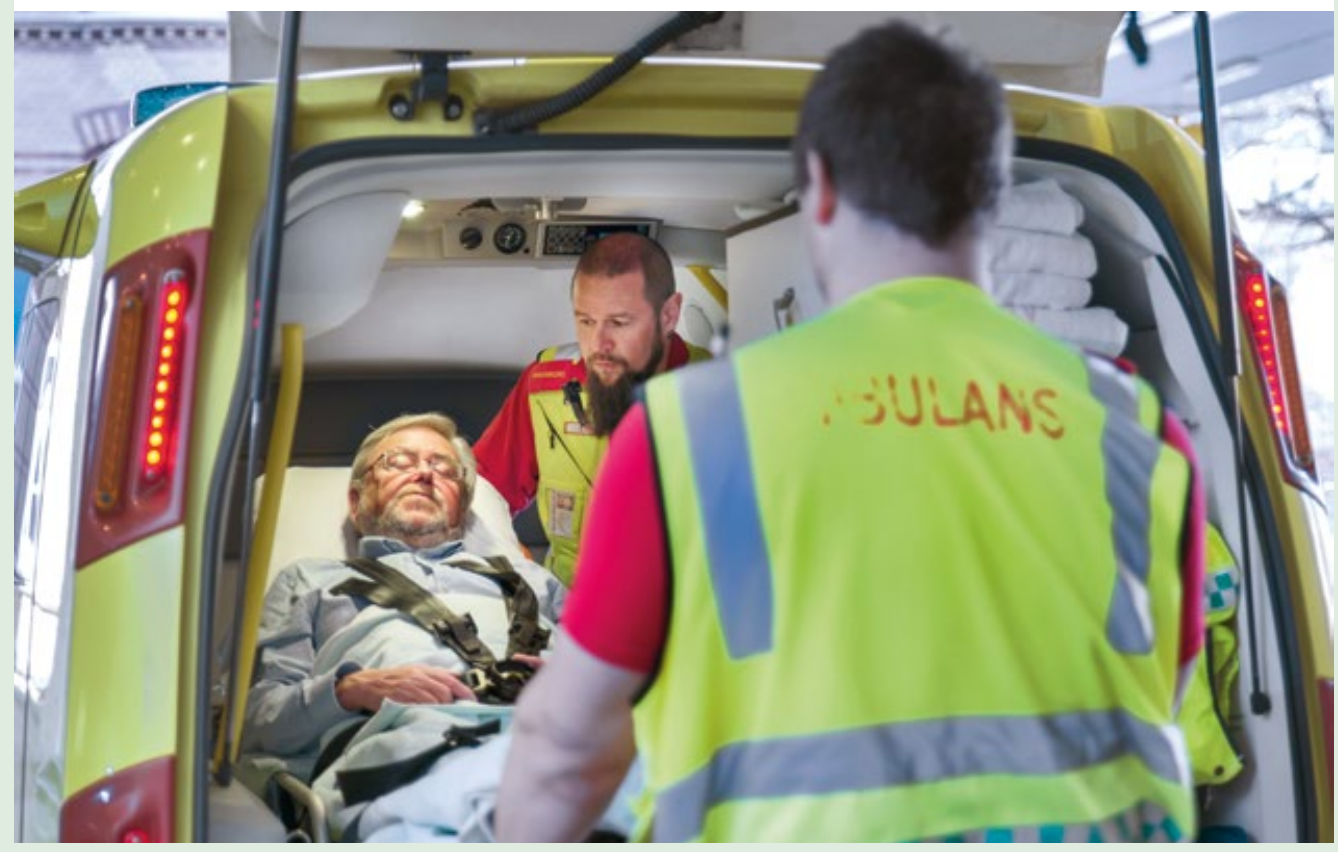




\section{Mye har skjedd på 40 år}

Fra Ford Nytt nr. 2, 1975

\section{Ford tar syketransporten \\ i Stjordal}

Ambulanseparken i Stjordal er utvidet med en ny bil. Fra for av var det to Transit or som beserget kjoringen. Forrige uke fikk ambulanseeier Torteit Fonn overlevert den nyo bilen - en Ford Grangda $3000 \mathrm{XL}$ med $151 \mathrm{HK}$ under panseret.

Den hat et tops utatyr pa like linje med de to andre ambulansene. Den

nye ambulansen or utstyrt med on $n y$

type sirene scm sa absolutt er eanet ti

a is bado folk og to ut av voipen

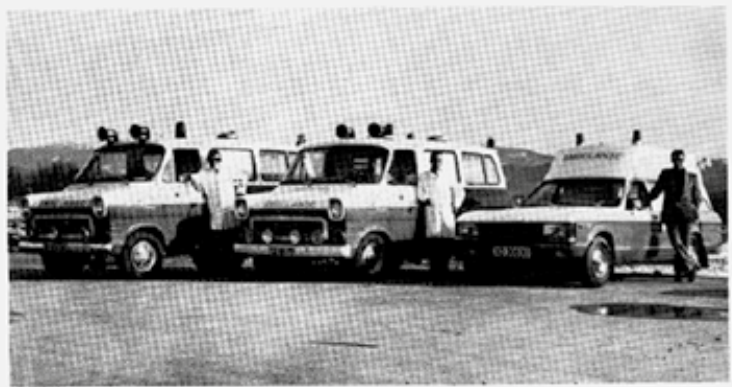

Akuttmedisinske tjenester på Helgeland, 2015

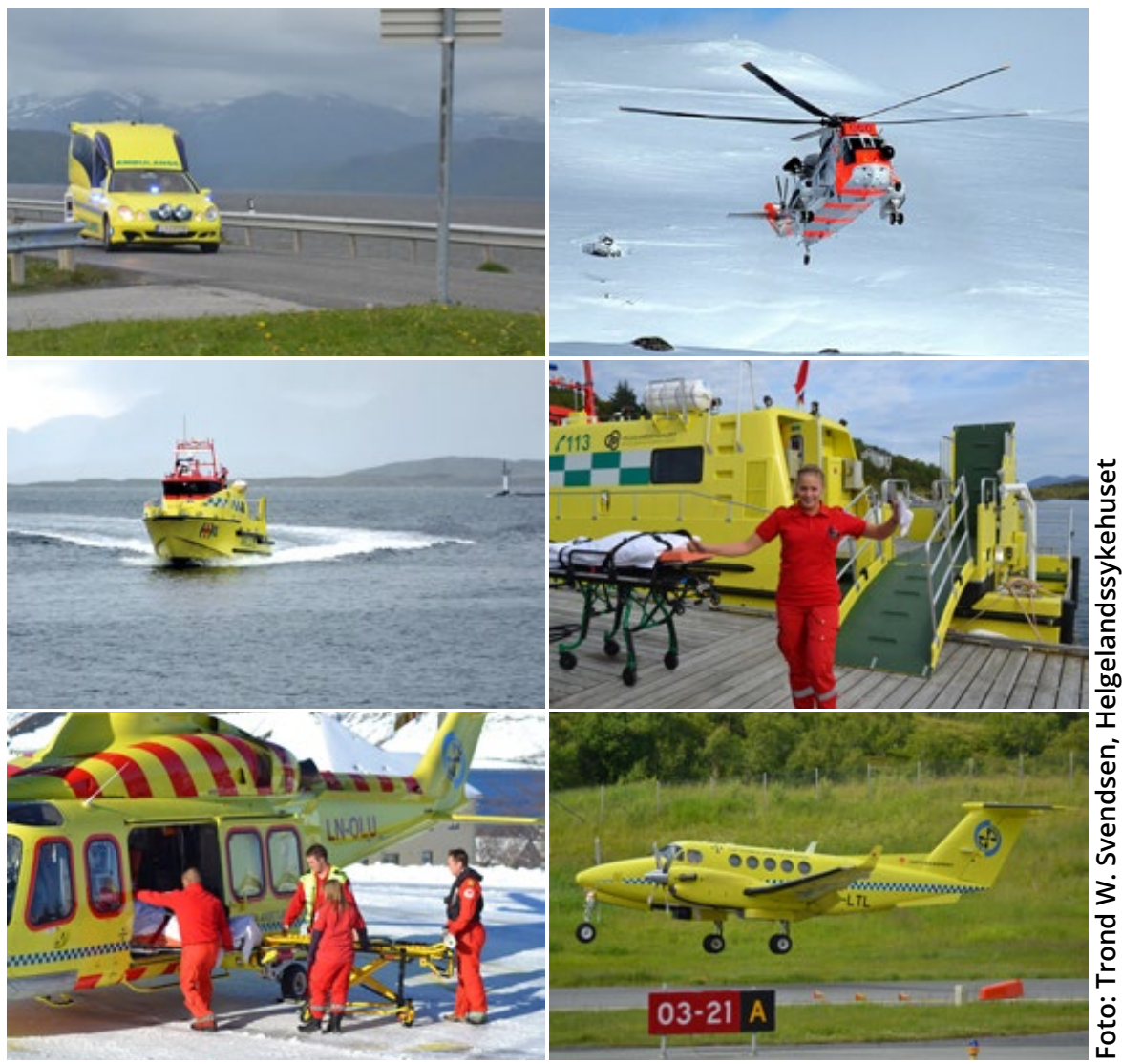




\section{Vi skaper pasientens helsetjeneste}

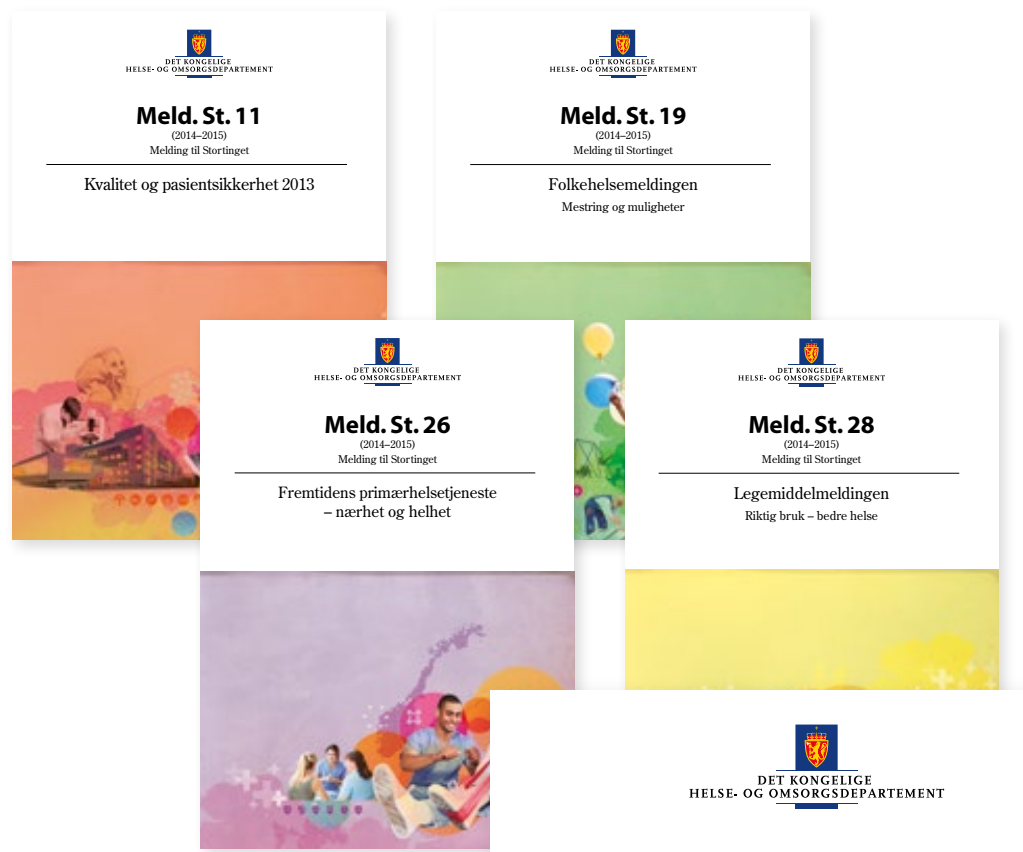

Meld. St. 11

(2015-2016)

Melding til Stortinget

Nasjonal helse- og sykehusplan (2016-2019)

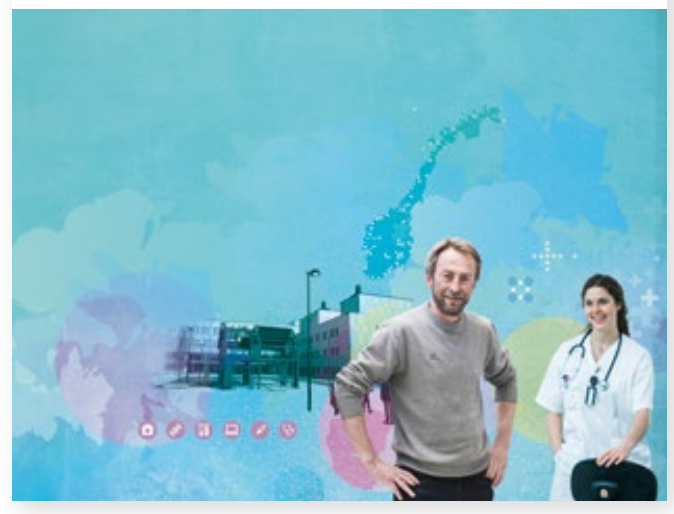


Les mer om Nasjonal helse- og sykehusplan: www.sykehusplan.no 


\section{Utgitt av:}

Helse- og omsorgsdepartementet

Offentlige institusjoner kan bestille flere eksemplarer fra:

Departementenes sikkerhets- og serviceorganisasjon

Internett: www.publikasjoner.dep.no

E-post: publikasjonsbestilling@dss.dep.no

Telefon: 22240000

Publikasjonskode: I-1167 B

Design og ombrekking: Kord

Trykk: Departementenes sikkerhets- og serviceorganisasjon 11/2015 - Opplag 1500 